Note

\title{
Physiological Characteristics of Bacillus sp. HR6 in the Process of Decomposing Bean Curd Refuse
}

\author{
HARUO MIMURA* AND SHINICHI NAGATA \\ Research Institute for Marine Cargo Transportation, Kobe University of Mercantile Marine, \\ 5-1-1, Fukae, Higashinada-ku, Kobe 658-0022, Japan \\ Received 8 October 1998/Accepted 27 February 1999
}

\begin{abstract}
Bacillus sp. HR6 and Bacillus subtilis ATCC6051 were compared in terms of their growth, activity of $\alpha$-amylase, and pattern of heat evolution. Bacillus sp. HR6 grew faster than B. subtilis ATCC6051 at temperatures higher than $45^{\circ} \mathrm{C}$. The maximum activities of $\alpha$-amylase were 304 and $280 \mathrm{U} / \mathrm{ml}$ for Bacillus sp. HR6 and B. subtilis ATCC6051, respectively. The highest activity of $\alpha$-amylase from Bacillus sp. HR6 was observed at $70^{\circ} \mathrm{C}$, and more than $60 \%$ of that was still seen at $75^{\circ} \mathrm{C}$. In case of $B$. subtilis ATCC6051, the maximum activity was observed at $65^{\circ} \mathrm{C}$, and $30 \%$ of that was seen at $75^{\circ} \mathrm{C}$. A rapid heat evolution was found for Bacillus sp. HR6 in comparison with that for $B$. subtilis ATCC6051 when cultivation was initiated in bean curd refuse at 50 ${ }^{\circ} \mathrm{C}$. However, there was no obvious difference in the heat evolution patterns between two strains at the starting temperature of $27^{\circ} \mathrm{C}$. These results suggest that Bacillus sp. HR6 has a higher activity in decomposing bean curd refuse than B. subtilis ATCC6051 at higher temperatures.
\end{abstract}

Key words : Bacillus sp. HR6/ $\alpha$-Amylase/Growth/Bean curd refuse/Heat evolution.

There is great interest in the microbial decomposition of waste materials due to concerns regarding the preservation of the natural environment and the conservation of resources. A bacterial strain that we isolated showed a high efficiency and usefulness in the decomposition of some food wastes such as bean curd refuse and fishes (Maeda et al., 1998; Mimura et al., 1995, 1999). The strain was taxonomically classified into the genus Bacillus (Mimura et al., 1995), and the physiological and biochemical characteristics of the strain, Bacillus sp. HR6, were similar to those of Bacillus subtilis. When the strain HR6 was mixed with $30 \mathrm{~kg}$ of bean curd refuse and incubated in the organic waste decomposition machine (BIO COSMO 100A, Sanyo Techno Co., Ltd., Kakogawa), the temperature in the chamber rose to $73^{\circ} \mathrm{C}$ after $9 \mathrm{~h}$. The net weight was reduced by about $70 \%$ after a $24-\mathrm{h}$ decomposition period (Mimura et al., 1995). In case

${ }^{*}$ Corresponding author. Tel : +81-78-431-6344, Fax : + 81-78-431-6365. of $B$. subtilis ATCC6051, which was employed as a representative strain of $B$. subtilis, the temperature did not reach $55^{\circ} \mathrm{C}$, and about $25 \mathrm{~kg}(83 \%)$ of bean curd refuse remained after a $24-\mathrm{h}$ decomposition process. Therefore, in this study, we tried to characterize Bacillus sp. HR6 closely in relation to the microbial decomposition of bean curd refuse.

Bacillus sp. HR6 was originally isolated from the soil. The procedure to select this strain from among 30 strains was as follows. First, we incubated each isolated strain in a nutrient broth containing $5 \mathrm{~g}$ of yeast extract (Difco, Detroit, Mi., USA) and $8 \mathrm{~g}$ of polypeptone (Nippon Seiyaku Co., Ltd., Tokyo) per liter. Second, $20 \mathrm{ml}$ of the cell suspension was adsorbed in some amount of sawdust, and then mixed with fresh fish meat with bones. Third, the mixture was kept at $35^{\circ} \mathrm{C}$ in an incubator for 3 days to observe its state of decomposition. Consequently, Bacillus sp. HR6 was chosen as the candidate to be used for food waste decomposition.

Strains of Bacillus sp. HR6 and Bacillus subtilis 
ATCC6051 were preincubated at $30^{\circ} \mathrm{C}$ for $24 \mathrm{~h}$ in a medium containing $5 \mathrm{~g}$ of yeast extract and $8 \mathrm{~g}$ of polypeptone per liter. Then $0.5 \mathrm{ml}$ of cell suspension was inoculated into a medium containing (per liter) 5 $\mathrm{g}$ of yeast extract, $8 \mathrm{~g}$ of polypeptone, $5 \mathrm{~g}$ of starch, which were autoclaved separately, and sodium chloride was added at concentrations of 0 to $87.7 \mathrm{~g}$ (1.5 $\mathrm{M})$. The medium was adjusted to $\mathrm{pH} 7.5$ by tetramethylammonium hydroxide.

The bacterial growth was monitored photometrically by measuring the turbidity of the cell suspension at $650 \mathrm{~nm}$ with a spectrophotometer (DU 640, Beckman, Fullerton, Calif., USA). The incubation temperature varied from 30 to $50^{\circ} \mathrm{C}$ in the absence of $\mathrm{NaCl}$ and it was fixed at $45^{\circ} \mathrm{C}$ in the presence of $\mathrm{NaCl}$. The growth rates, doublings per $h$, were calculated from the growth curve. The turbidity used for the analysis was from 0.05 to 0.6 in optical density, be-
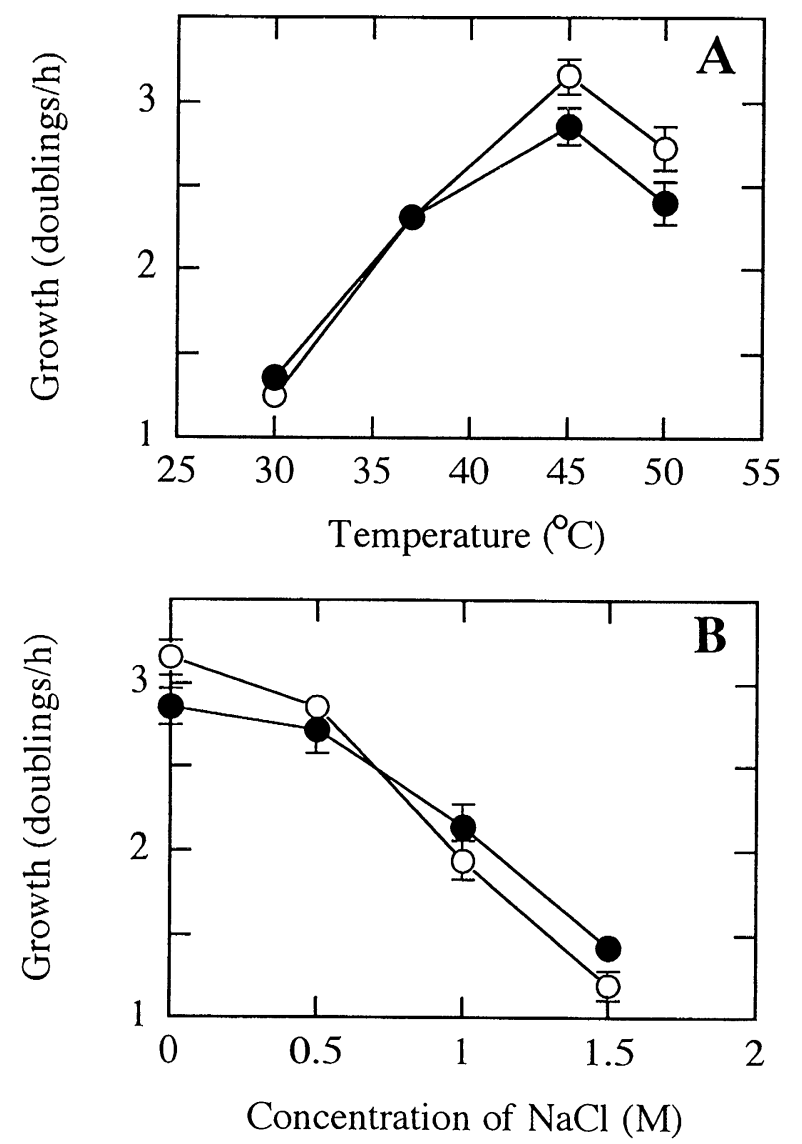

FIG. 1. Growth rates for Bacillus sp. HR6 and Bacillus subtilis ATCC6051 at given temperatures in the absence of $\mathrm{NaCl}(\mathrm{A})$ and at $45^{\circ} \mathrm{C}$ in the presence of various concentrations of $\mathrm{NaCl}(\mathrm{B})$. The growth experiments for Bacillus sp. HR6 (O) and B. subtilis ATCC6051 (O) in experimental conditions were carried out three times independently. Each point represents the mean of the doublings per $h$, and the standard deviations are represented by the error bars. cause there was linearity in this range on a logarithmic scale.

The growth rates of both strains were shown in Fig. $1 \mathrm{~A}$. The doublings per $h$ for both strains were almost the same below $37^{\circ} \mathrm{C}$. A difference was observed at temperatures higher than $45^{\circ} \mathrm{C}$, i. e., the values and their S. D. at $45^{\circ} \mathrm{C}$ were $3.16 \pm 0.10$ and $2.86 \pm 0.11$ (doublings/h) for Bacillus sp. HR6 and B. subtilis ATCC6051, respectively. The doublings per $h$ were reduced with an increase of the temperature from 45 to $50^{\circ} \mathrm{C}$. Since bacteria in the environment are sometimes exposed to stresses such as salt, heat, $\mathrm{pH}$ change and UV radiation, we examined the bacterial growth in the presence of $\mathrm{NaCl}$ (Fig. 1B). With increasing $\mathrm{NaCl}$ concentrations from 0.5 to $1.5 \mathrm{M}$, the growth rate of Bacillus $\mathrm{sp}$. HR6 became smaller than that of $B$. subtilis ATCC6051. In the presence of $1.5 \mathrm{M}$ $\mathrm{NaCl}$, the doublings $\pm \mathrm{S}$. D. per $\mathrm{h}$ for Bacillus sp. HR6 and $B$. subtilis ATCC6051 were $1.2 \pm 0.10$ and 1.43 \pm 0.03 , respectively.

In the microbial decomposition of bean curd refuse, attention must be paid to the possibility that many types of bacteria might prevent the efficient decomposition of waste materials by Bacillus sp. HR6. A large value of the doublings per $h$ at a high temperature is one of the critical factors for a strain to be dominant in such a bacterial community. The growth of Bacillus sp. HR6 was enhanced by increasing the incubation temperature in the absence of $\mathrm{NaCl}$, but repressed with an increase of $\mathrm{NaCl}$ concentration, compared to that of $B$. subtilis ATCC6051. These results indicate that Bacillus sp. HR6 is useful in decomposing food waste material containing lower salt concentrations.

The extracellular $\alpha$-amylase activities of Bacillus sp. HR6 and B. subtilis ATCC6051 were measured by a modified DNS method (Park et al., 1997). The DNS solution contains $300 \mathrm{~g}$ of potassium tartrate, $10 \mathrm{~g}$ of 3, 5-dinitrosalicylic acid, and $32 \mathrm{~g}$ of $\mathrm{NaOH}$ (per 1.3 liter). After a $24-\mathrm{h}$ incubation at $30^{\circ} \mathrm{C}$ in the medium which was the same as that used for the measurement of the growth rate, the cell suspension was centrifuged twice $(12,000 \times \mathrm{g}, 5 \mathrm{~min})$ at $4^{\circ} \mathrm{C}$ and the cell free supernatant was stored at $4^{\circ} \mathrm{C}$ before use. Starch (Nacalai Tesque Co., Ltd., Kyoto), the substrate of $\alpha$-amylase, was dissolved in $50 \mathrm{mM}$ of potassium phosphate buffer, $\mathrm{pH} 7.5$, to make a $6 \%(\mathrm{w} / \mathrm{v})$ solution. A mixture containing $250 \mathrm{\mu l}$ of the starch solution and $1 \mathrm{ml}$ of the supernatant was incubated at given temperatures. Two hundred and fifty $\mu$ I of aliquot in the reaction mixture was taken out at certain intervals and mixed with $250 \mu \mathrm{I}$ of the DNS solution. After being boiled for $5 \mathrm{~min}$, the sample was mixed with $5 \mathrm{ml}$ of distilled water, and the absorbance at 540 $\mathrm{nm}$ was measured. The $\alpha$-amylase activity was 
calculated from the slope of the linear regression curve using more than three points of data, with the correlation coefficient over 0.96 for every experiment. One unit of enzyme activity was defined as the amount of enzyme to make $1 \mathrm{nmol}$ reducing sugar as maltose from starch per min.

When Bacillus sp. HR6 was cultivated with bean curd refuse in a Dewar flask for $24 \mathrm{~h}$, the reduction percentage of carbohydrates was $19.4 \%$, which was larger than those of proteins and lipids (Mimura et al., 1995). During the microbial decomposition of bean curd refuse in an organic waste decomposition machine, the temperature in bean curd refuse became over $70^{\circ} \mathrm{C}$ (Mimura et al., 1995). Thus, we expected that the extracellular $\alpha$-amylase of Bacillus sp. HR6 would possess a higher activity at an increasing temperature or be produced in larger amounts than that of B. subtilis ATCC6051.

Figure 2 shows the effect of temperature on the activity of $\alpha$-amylase. The activity of $\alpha$-amylase from Bacillus sp. HR6 was at the maximum, $304 \mathrm{U} / \mathrm{ml}$ at $70^{\circ} \mathrm{C}$, over $60 \%$ of which remained at $75^{\circ} \mathrm{C}$. On the other hand, the maximum activity for $B$. subtilis ATCC6051 was $280 \mathrm{U} / \mathrm{ml}$ at around $65^{\circ} \mathrm{C}$, which was reduced by $70 \%$ when the reaction temperature was increased to $75^{\circ} \mathrm{C}$. The optimum temperature for the extracellular $\alpha$-amylase activity of Bacillus sp. HR6 was $5^{\circ} \mathrm{C}$ higher than that of $B$. subtilis ATCC6051. In addition, the activity at $75^{\circ} \mathrm{C}$ was much higher than that of $B$. subtilis ATCC6051. These results indicate that $\alpha$-amylase of Bacillus sp. HR6 reacts better than

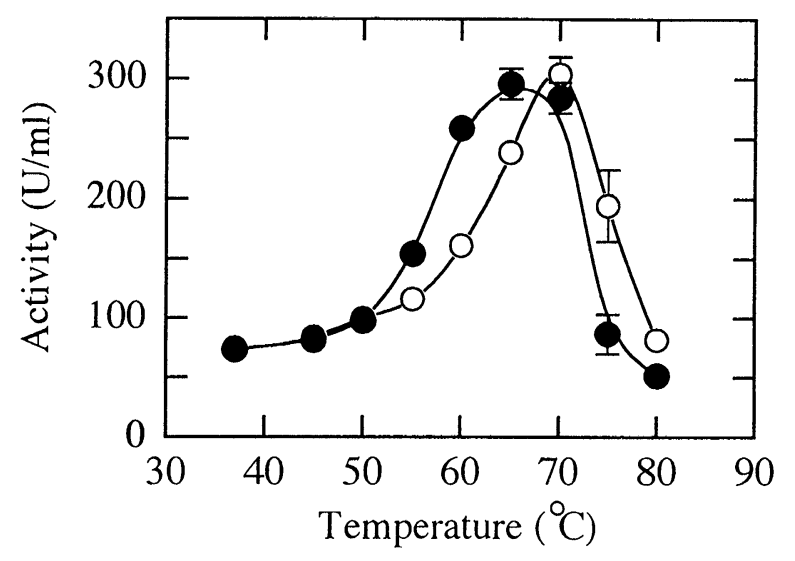

FIG. 2. Effect of temperature on the extracellular $\alpha$-amylase activity of Bacillus sp. HR6 and Bacillus subtilis ATCC6051. The supernatant of Bacillus sp. HR6 (O) and $B$. subtilis ATCC6051 (O) grown in the medium containing $0.5 \%(\mathrm{w} / \mathrm{v})$ of starch was used to measure the initial $\alpha-a$ mylase activity at given temperatures. Each point represents the mean of the three replications, and the standard deviations are represented by the error bars. that of B. subtilis ATCC6051 at higher temperatures in the decomposition of bean curd refuse. Since the dry weights of Bacillus sp. HR6 and B. subtilis ATCC6051 strains were 3.7 and $3.6 \mathrm{mg} / \mathrm{ml}$, respectively, the specific activity of $\alpha$-amylase ( $\mathrm{U} / \mathrm{mg}$ of dry weight cells) for each strain showed the same pattern as in Fig. 2 (data not shown), indicating that the amount of enzyme produced from Bacillus sp. HR6 was almost equal to that from $B$. subtilis ATCC6051.

We also measured the heat evolution in bean curd refuse after being mixed with the strain of Bacillus sp. HR6 or B. subtilis ATCC6051. Cells grown in $500 \mathrm{ml}$ of the medium containing $5 \mathrm{~g}$ of yeast extract and $8 \mathrm{~g}$ of polypeptone (per liter) were washed with a centrifuge and suspended in $50 \mathrm{ml}$ of distilled water. The cell suspension was mixed with $700 \mathrm{~g}$ of bean curd refuse (Ogura Food Co., Ltd., Kakogawa) which had been previously autoclaved. The mixture was placed in a Dewar flask $(\phi 11.5 \times 20 \mathrm{~cm})$, the surface of which was covered with autoclaved cotton to prevent thermal loss and bacterial contamination. The temperature change in the flask was measured with a thermocouple (E52-CA20C, Omron, Kyoto) connected with a chart recorder (E55A-C3, Omron, Kyoto).

When the strains were cultivated in the bean curd refuse product at the initial temperature of $50^{\circ} \mathrm{C}$, the temperature was once reduced within $3 \mathrm{~h}$ of incuba-

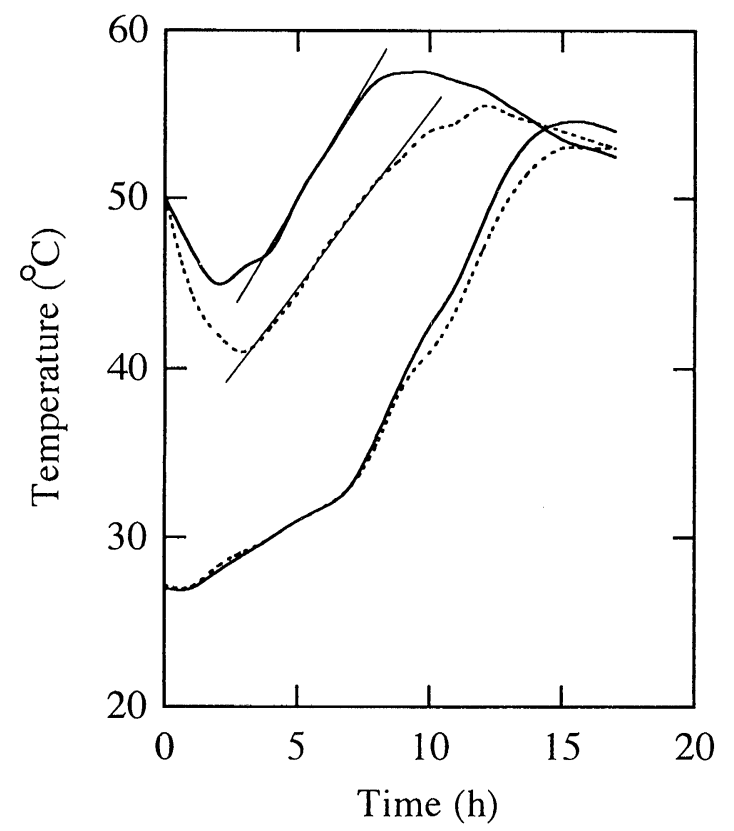

FIG. 3. Heat generation patterns for Bacillus sp. HR6 (-) and Bacillus subtilis ATCC6051 (........) cultivated in the bean curd refuse product at the initial temperature of 50 and $27^{\circ} \mathrm{C}$, respectively. Bean curd refuse was stored in a Dewar flask which was kept at $30^{\circ} \mathrm{C}$ in the incubator. 
tion. Thereafter, the temperature of the bean curd refuse mixed with Bacillus sp. HR6 began to increase and reached to $57.5^{\circ} \mathrm{C}$ at $9 \mathrm{~h}$ of the incubation. A similar pattern was observed for the heat evolution by $B$. subtilis ATCC6051. The ratios calculated from the slopes (drawn in Fig. 3 ) of the heat evolution curves for Bacillus sp. HR6 and B. subtilis ATCC 6051 were 2.50 and $2.15^{\circ} \mathrm{C}$ per $\mathrm{h}$, respectively. The decrease of the temperature observed during the initial stage seems to be related with the heat outflux from the Dewar flask. When the starting temperature was 27 ${ }^{\circ} \mathrm{C}$, the heat evolution patterns of the strains were almost the same.

The heat evolved in the microbial decomposition of food waste caused the thermal death of other contaminating bacteria (Hamamatsu et al., 1993). Thus, a rapid growth followed by the heat evolution is primarily required when bacteria are used for microbial decomposition. Bacillus sp. HR6 showed a more accelerated rate of heat evolution (Fig. 3) and grew faster (Fig. 1A) than B. subtilis ATCC 6051 at the increased temperatures. These results support the likelihood that Bacillus sp. HR6 is superior to B. subtilis ATCC6051 in terms of food waste decomposition.

Mata-Alvarez and Llabrés (1992) have proposed that the anaerobic decomposition of the organic wastes can be used to produce methane gas which in turn can be used to produce electricity. In our system, we have observed the high temperature of $73^{\circ} \mathrm{C}$ in the chamber when a bean curd refuse was decomposed with aeration and stirring (Mimura et al., 1995). Thus, the heat produced by microbial decomposition can be possibly and efficiently utilized for a variety of ways to save energy.

\section{ACKNOWLEDGMENTS}

We thank Mrs. Yaobing Wang and Mr. Kenji Maeda for their technical assistance.

\section{REFERENCES}

Hamamatsu, K., Hasumi, F., Okajima, J., and Okura, I. (1993) Biological heat generation by the cultivation of Alternaria alternata in rice bran. Appl. Biochem. Biotechnol., 43, 141-145.

Maeda, K., Mimura, H., and Nagata, S. (1998) Toxicity assessment and application as the soil fertilization of bean curd refuse decomposed by Bacillus sp. HR6 (in Japanese). Kankyo Gijyutsu, 27, 813-817.

Mata-Alvarez, J., and Llabrés, P. (1992) Anaerobic digestion of the Barcelona central food market organic wastes: Experimental study. Bioresource Technol., 39, 39 - 48.

Mimura, H., Maeda, K., Higashi, T., and Nagata, S. (1995) Biological decomposition of food wastes by Bacillus sp. HR6 (in Japanese). Kankyo Gijyutsu, 24, 513-516.

Mimura, H., Maeda, K., and Nagata, S. (1999) Chromatographic analysis of bean curd refuse decomposed by Bacillus sp. HR6. Biocontrol Sci., 4, 21-24.

Park, Y., Uehara, H., Teruya, R., and Okabe, M. (1997) Effect of culture temperature and dissolved oxygen concentration on expression of $\alpha$-amylase gene in batch culture of spore-forming host, BaciIlus subtilis 1A289. J. Ferment. Bioeng., 84, 53-58. 